\title{
INTER-MIND PHENOMENA IN CHILD NARRATIVE DISCOURSE
}

\author{
Barbara Bokus ${ }^{1}$
}

\begin{abstract}
A review of the current literature shows that by the age of two and a half (and probably earlier), children have already acquired a rich working knowledge of human intentionality and goal-directed action (Stein \& Albro 1997: 7; Mandler 1998). The paper focuses on the ways in which children use this knowledge to tell stories from pictures. The story is the description of the actions performed by animate actors. We distinguish the main actors (protagonists in the narrative line) and the background actors (participants in the narrative field) who can observe and interpret what is going on in the main action. So the narrative text contains not only the action presented by the story-teller (landscape of action) but also how this action is interpreted by the story characters (landscape of consciousness). They are all thinking minds who can think similarly or differently about the plot. And the narrator uses characters' minds to produce different representations of the story (Bokus 1998, 2000). The narrator can confront one interpretation with another, and a) makes choices of the "true" representation of the main action (in doing this the child plays the role of the omniscient and omnipresent story-teller who is directly in touch with the ontology of the story), or b) presents a possible but not a certain story reality (the listener is not told how things are but rather how they seem to be). Therefore we can speak about the interplay of the narrator's mind and the minds of story characters in a kind of internal narrator's dialogue. The storyteller creates different minds and alternative ways of interpreting the main action. Also shown are examples of such inter-mind phenomena in the stories told by preschool children.
\end{abstract}

Keywords: Child Discourse, Dual Narrative Landscape, Narrative Line, Narrative Field, Theory of Mind.

\section{Introduction}

More than twenty-five years ago (in 1978), in her influential article entitled "The child as psychologist: Construing the social world" Maureen M. Shields wrote as follows:

"Surely it is time that the cognitive psychologist came face to face with the young naive psychologist, and turned his sophisticated techniques to building a more adequate model of the growth of man's concept of man" (Shields 1978: 556).

${ }^{1}$ This article is based on an invited paper presented by the author at the Turku Symposium on First language Acquisition (Turku, 1-2 September 2000) and a text of an invited lecture prepared for the Lublin conference "Jedna lub więcej narracji" [One or more narrations] (Święta Katarzyna, 11-14 September 2003). Preparation of the article was partially supported by Grant BST 671/17. Grateful acknowledgment is due to Professor Grace Wales Shugar for her careful reading and constructive comments on an earlier version of this text. 
Developmental cognitive science has undergone great changes since 1978, and has developed theoretical systems to show how and when children develop a folk psychology or "theory of mind", the understanding of others as psychological beings having mental states as beliefs, desires, emotions and intentions. According to Meltzoff (1995: 839), recent research on children's understanding of mind has been focused on two questions:

(a) mentalism: "How and when do children begin to construe others as having psychological states that underlie behavior?"

(b) representational model of mind: "How and when do children come to understand mental states as active representations of the world and not simply copies or imprints of it?"

Of crucial importance in social cognition development (see Tomasello 1999) is a continuous progression in children's understanding of others, as follows:

-“animate agents, in common with all primates (infancy);

- intentional agents, a species-unique way of understanding conspecifics, which includes an understanding of both the goal-directed behavior and the attention of others (one year); and

- mental agents, the understanding that other persons have not just intentions and attention as manifest in their behavior, but also thoughts and beliefs which may or may not be expressed in behavior - and which may differ from the "real" situation (four years)". (Tomasello 1999: 179)

False belief tests conducted by many researchers have shown the apparent acquisition at around age 4 of an ability to understand the representational status of mind. In some studies a narrative context influenced children's false belief reasoning. When children (even 3-year-olds) are given the opportunity to link discrete events into a coherent narrative, they have no problem demonstrating an understanding of others' minds. Being able to recount the narrative is sufficient for successful performance (Lewis et al. 1994: 397). This confirms earlier results by Macnamara, Baker, and Olson (1976). Over twenty-seven years ago these authors, and later Abbeduto and Rosenberg (1985), showed that a story context facilitates children's understanding of presuppositions of mental states conveyed by the verbs "know", "remember", "forget", "think", even if the story does not provide direct information about such mental states.

In light of the above mentioned studies, it is difficult to understand an asymmetry in the literature concerned with the child as psychologist, between research on theory of mind and research on narrative development (see Bokus 1996a; Nicolopoulou 1999). Compare the following (see Nicolopoulou \& Richner 1999a: 1):

- theory-of-mind research: "Children begin to talk about mental states at 2-3 years 
and develop a representational theory of mind around 4 years of age" (e.g., Astington 1993; Gopnik \& Meltzoff 1997; Flavell \& Miller 1998);

- narrative research: "Children begin to develop psychological portrayals of characters around 7 years and consolidate this ability around 10 years of age" (e.g., Bamberg \& Damrad-Frye 1991; Hudson \& Shapiro 1991; Stein \& Albro 1997; KielarTurska 1999).

Two independent projects (similar in main features) were conducted by Nicolopoulou (1999a, 1999b) and Bokus (1996a, 1998, 2000) in an effort to resolve the above-mentioned discrepancy. Nicolopoulou and her collaborators stated that, in most narrative research, experimental elicitation techniques restrict children's character representation. Adult-oriented and artificial contexts for story production exclude resources and motivations that lead children to generate richer and more sophisticated stories (Nicolopoulou \& Richner 1999a: 1). The solution proposed by Nicolopoulou is to examine spontaneous narratives produced in the social context of children's everyday group life. In this context children tell stories not only to adults but primarily to each other. In Bokus' studies children tell stories either to adult or to child listeners. The most significant feature of Bokus' studies is that the listener's sole means of learning what happened is through the child narration (The narrator talks about a picture/picture-book which only he or she can see. In such a situation the child narrator is the only source of new information on story topic). In both projects, by Nicolopoulou and by Bokus, children not only tell stories but also act out their stories. The narration is the preparatory step enabling children to play the different roles of the story characters during a performance. The narrator knows for what purpose he or she reports information to the listener. The task makes human sense in the terms of the author of Children's minds (Donaldson 1978: 17). The present paper is concerned with actions presented in narrative discourse and with the mental states that young narrators ascribe to their story characters. The theoretical background of this study is derived from Bruner's conception of a dual narrative landscape (Bruner 1986) and Bokus' conception of two narrative dimensions - narrative line and narrative field (Bokus 1996b).

Bruner's term subjunctive reality denotes a possible, not a certain, reality which is not entirely determined by the speaker, but is partially created by the listener (see also Eco 1994). The discourse processes that are used to subjunctivize reality are fundamental to the language of narrative, and to the creation of a dual landscape: one of the world of action depicted in the story, the other of the world of consciousness in the minds both of story characters and narrator (Astington 1990). According to Bokus (1996a), story characters can be distinguished as subjects of the narrative line and subjects of the narrative field. The narrative line presents the course of changes of referenced reality over time. Agents of actions changing referenced reality are the heroes of the narrative line. Subjects that are not engaged directly in changes of referenced reality, figuring, as it were, in the background, we have called participants in the narrative field. In light of our previous studies (Bokus 1996b), narrators introduced field subjects related in some way to subjects in the narrative line, as follows:

1) spatial relation

2) observer - observed relation \{coded in the landscape

of action\} 
3) explainer - explained relation \{coded in the landscape

4) evaluator - evaluated relation of consciousness $\}$

In this paper, we explore how narrators ascribe to field subject-observers attempts to interpret what is happening in the narrative line (explainer - explained relation and evaluator - evaluated relation).

\section{Problem}

While many studies deal with children's understanding of action and consciousness in stories they listen to (Britton \& Pellegrini 1990), the current study is an attempt to approach two other questions:

1. When do children start to produce stories with a dual landscape?

[This question was formulated by Astington (1990: 167), and is repeated here]

2. How is the duality (landscape of action and landscape of consciousness) constructed in children's narratives?

\section{Subjects and research design}

256 preschoolers (from families with higher education) were studied, 64 in each of three age groups $(3 ; 3-3 ; 9,4 ; 3-4 ; 9,5 ; 3-5 ; 9$ and $6 ; 3-6 ; 9)$.

The children recounted to peer listeners the adventures of the heroes in three picture books $(\mathrm{A}, \mathrm{B}, \mathrm{C})^{2}$. The heroes, Jacek and Wacek (children in the forefront), are the same in all the picture books. Three types of situation of the heroes were represented in the story books: 1/ a situation of real danger (story book A), 2/ a situation of potential danger (story book B), 3/ a positive (desired) situation (story book $\mathrm{C}$ ). Each picture book was in two versions, the difference being the relationship between field subjects and line subjects. Each narrator recounted two adventures (A, B or A, C), one that happened in the presence of a peer (children in both forefront and background of the picture), and the other in the presence of a non-peer (children in the forefront and an adult in the background - see Appendix 1). The research design was balanced for age, gender and order of narration in these two experimental variants.

The investigation was conducted as an integral part of a sociodramatic play organized by the experimenter $(\mathrm{E})$ in the nursery school. A child in the narrator role constructed a narrative in conversation with another child in the role of stage manager who later directed the children acting out the story. The narrative was thus the basis of the story of the whole performance. Only the narrator had access to the story book pictures (the listener, then stage manager, could not see them). 512 stories were obtained in the studies

\footnotetext{
${ }^{2}$ These picture-books (in colors) are presented in Bokus 2000: 42-46.
} 
and analyzed (see method of analysis below).

\section{Narrative text conception and method of narrative analysis}

A narrative can be expressed through other media (e.g., painting, dance), but it is through language that narratives find their most explicit form (Ely, McCabe, Wolf, \& Melzi 2000). This paper deals with narrative treated as a verbal representation of events that follow one another in time (see e.g., Labov \& Waletzky 1967; Bamberg 1997).

A narrative text, as a semantic unit of language in use (Halliday \& Hasan 1976), refers to a changing reality (Bokus 1992). In psychology, changing reality is grasped in the notion of situation as the state of reality at a given moment (Tomaszewski 1975). In semantics, the notion of situation is understood in two ways: One, as the context in which an utterance occurs, and the other, the state of reality described by the utterance or what is talked about (Lyons 1977), i.e., a reference situation (according to Shugar 1976, 1998). The changing nature of reality represented in a narrative can be treated in categories of reference situations. Therefore a narrative text can be operationally defined as a chain of reference situations (Bokus 1991, 1992, 1998).

In the psychological definition, every situation, hence also reference situation, is always someone's situation, i.e., is assumed to have some subject, animate or treated (by a speaker) as animate. A situation cannot be identified without both identifying its subject and describing the activity or state of that subject. A reference situation is mentally constructed by the speaker and represents a state of reality grasped in the perspective of the selected subject. To make this clear, let us say that reference situations comprising a text are distinguished according to the situational subject, and to the state of the situational subject.

The state of activity of any subject can embrace:

- the state of external activity accessible to observation (presented in the landscape of action),

and/or

- the state of the subject's internal activity (mental state), which is not directly accessible to observation but is inferred by the narrator (and presented in the landscape of consciousness, in Bruner's terms, 1986).

Mental states conveyed by the illocutionary verbs "know", "think", and similar ones, are not only subjective (i.e., belonging to one or another individual), but are also objective, i.e., making reference to something in the world. They have a representational content in Searle's (1983) terms, they are about something (Searle 2002), here: About situations of narrative line subjects (heroes of the story).

In this article we analyze mental states attributed by preschoolers to narrative field subjects: What they know, think, or feel, or do not know, think or feel (after Bruner 1986: 14) in reference to the line of main action observed by them (and described in the narrative line).

For example,

(1) Dziewczynka patrzy w Jacka...

I myśli ona: "Jacek fruwa... dobrze... 
Jacek tak dobrze fruwa... jak motyl"

'A little girl is watching Jacek...

And she is thinking: Jacek's flying... good...

Jacek flies so good... like a butterfly' [L.A. 5;4]

\section{Results}

We didn't observe any mental attributions by three-year-old narrators. The analysis dealt only with narratives by 4-7-year-olds.

It turned out that field subjects were ascribed states of consciousness which were attempts at interpretations about the content of the narrative line. Attributing these interpretations to narrative field subjects, the narrator presented the main action from their perspectives. Our analyses confirmed that the narrator was taking another mind's perspective. How otherwise could one explain that the same action taking place in the foreground of the picture was interpreted in different categories by peer and non-peer field subjects. Analyses (Bokus 1998) have shown that narrators aged 4 to 7 seem to attribute a different optic to symmetrical and asymmetrical participants in reference to the actions in the narrative line. To adults they impute "why" interpretations in terms of causes of a given state of action or of absence of a desired action, and interpretations in categories of consequences of action (rewards and penalties for the heroes).

For example,

Pan rybak sobie myśli : "Dlaczego Jacek $i$ Wacek bawia się sami nad rzeka. Zgubili się mamusi?"

'The fisherman is thinking: "Why are Jacek and Wacek playing alone beside the river. Did they lose their mummy?"' [S.K. 4;9]

(3) On...ten rybak ... to on się martwit : "Czy chłopczyk nie będzie chory?

'He... that fisherman... he was wondering: "Will that boy be sick?"' [L.J. 4;7]

To peer participants, on the other hand, narrators impute "what for", "how to achieve a given goal", and "was it achieved", interpretations that accentuate teleological links in episodic action (motive/goal of heroes' action, realization of the action plan /steps and manner of action/, and result of action).

For example,

No i taki chtopczyk stanat $i$... i...

I nie wiedziat, jak Jacek ...wyciagnie Wacka, jak...

'And a boy was standing (there) and... and...

And he didn't know how Jacek... will pull Wacek out, how...' [Z.S. 5;4]

Figure 1 shows the frequencies of each mental state category attributed to narrative field subjects in reference to heroes' adventures. 
Fig. 1. Categories of mental representations attributed to narrative field subjects - child (Fig.1a), adult (Fig. 1b)

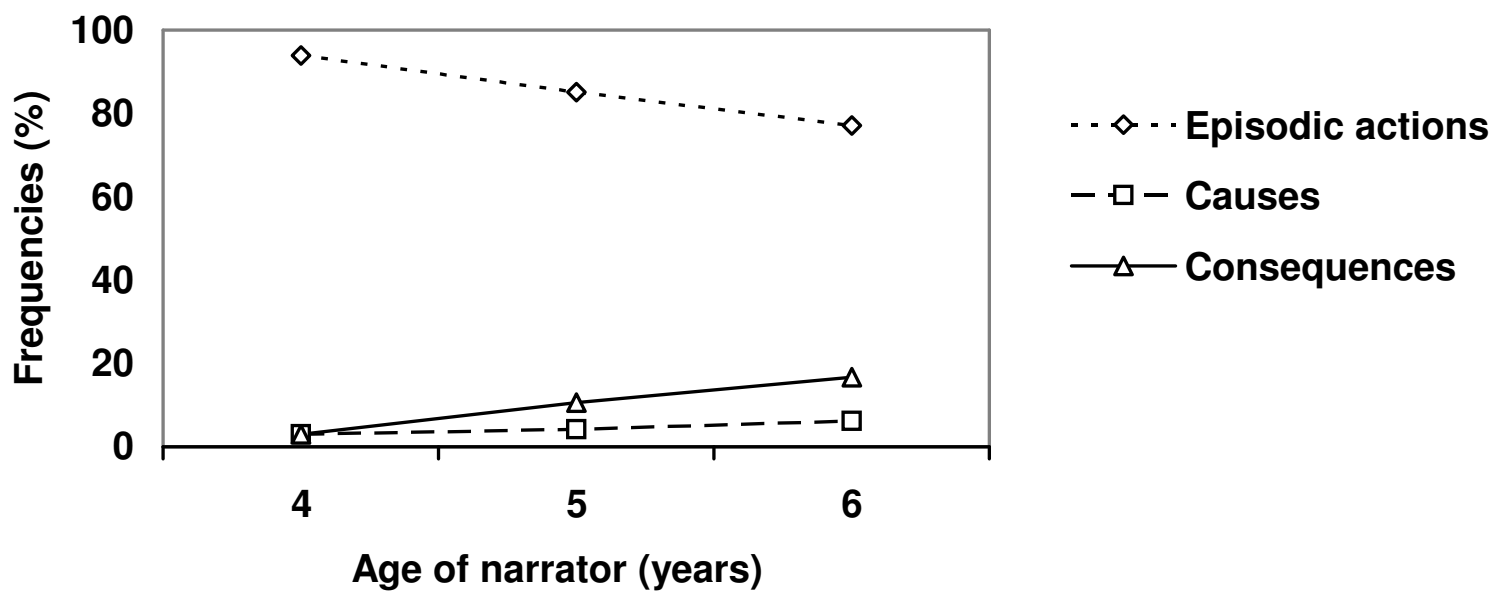

Fig.1a. Mental representations attributed to peer participant in the narrative field

A loglinear analysis for mental state attributions was conducted, and showed a significant main effect of the following interaction: Symmetrical vs. asymmetrical relationship between narrative line subjects and narrative field subjects $\mathrm{X}$ mental state category attributed to narrative field subjects $\left[\mathrm{L}^{2}(1)=92.12758, \mathrm{p}<0.0000005\right]$. Detailed data of loglinear analysis are presented in Appendix 2.

One may say that narrators aged 4 to 7 impute to adult and peer participants in the narrative field different interpretations of what is happening in the narrative line. The adult (to whom attributions dealt with categories of causes - consequences of heroes' actions interpreted as desired actions or not) seemed to be perceived as the personification of rules instilled in children through their upbringing. On the other hand, the child in the narrative field is treated as a potential participant in the heroes' action. The presence of a child in the background of the picture inclines the narrator to clarify the heroes' action and the possibility of reaching the intended result (Bokus 1998). This is in accordance with the claim that children show a basic cognitive identification between their own actions and those of peers (Musatti 1986: 41). 


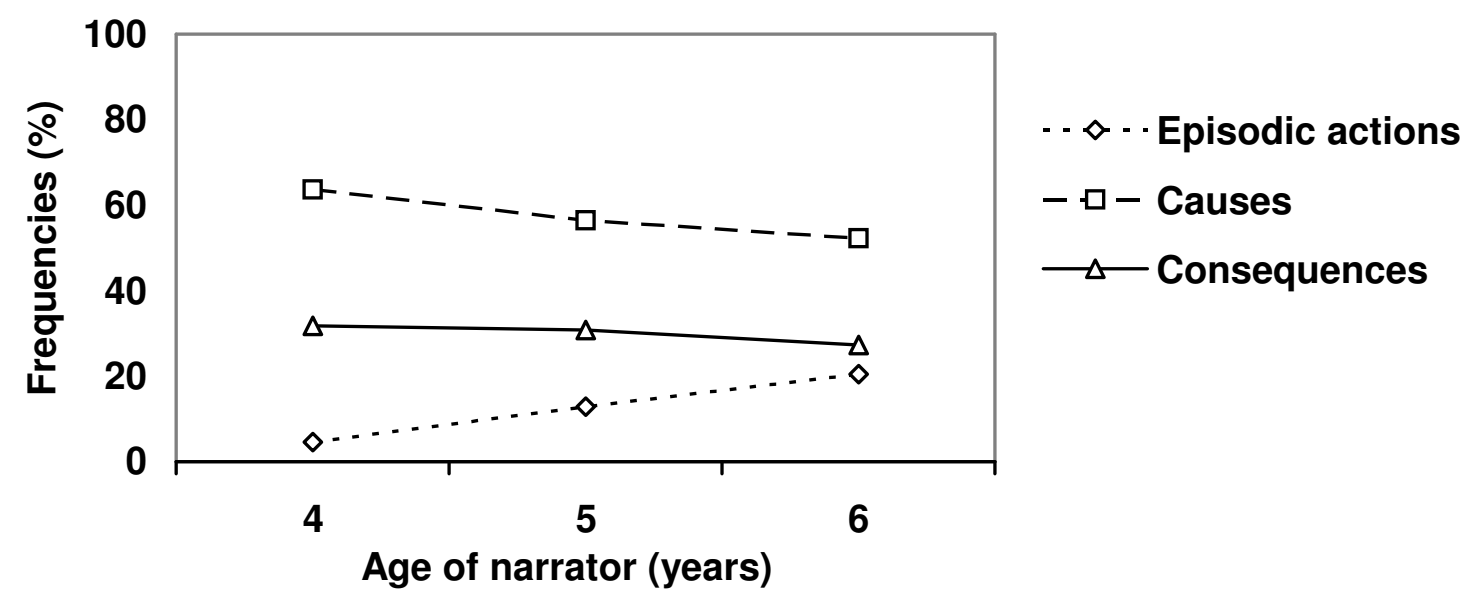

Fig.1b. Mental representations attributed to adult participant in the narrative field

Interpretations attributed to field participants (regardless of symmetry) fell into three categories, now presented with examples:

\section{Incomplete interpretation}

(5) I sobie myślat:

"Dlaczego dzieci sq nad rzekq sami, bez mamusi? Uciekli mamusi?"

A to było tak. Tomek chciał pokazać żabki dla Wacka... i Jacka nad rzekq.

Mamusia nie dała iść nad rzekę.

No to uciekli mamusi. I polecieli.

Nie znaleźli Tomka. Nie znaleźli żabki.

Ale byta tam pitka.

I grali. Znaleźli piłkę i grali.

'And he was thinking:

"Why are the children at the river without (their) Mummy? They ran away from (their) Mummy?"

And it was like this. Tomek wanted to show froggies for Wacek and ... Jacek at the river.

They couldn't get Mummy to go to the river.

So they ran away from Mummy. And they ran off.

They didn't find Tomek.

They didn't find any froggies.

But there was a ball there.

And they played. They found a ball and played.' [J.G. 5;8] 


\section{Wrong interpretation from the narrator's perspective (totally or partially)}

(6) Jacek fruwat nad taka, tak fiu... fiu... (demonstruje) A mamusia patrzy, jakie wielkie muchy lataja nad taka.

Nie wie, że to Jacek tak fruwa, no bo nie kazała mu wychodzić z domku, z tym drugim... no... z Wackiem.

A to Jacek fruwat, nie żadna mucha (dziecko śmieje się).

Bo byt Jacek niegrzeczny $i$ ten Wacek.

I wyszli z domku.

'Jacek was flying over the field, like this fiu... fiu (showing how).

And Mummy is watching the great big flies flying over the field.

She doesn't know that it's Jacek flying, 'cos she didn't tell him he could go outside the house, with the other one - mm - with Wacek.

And so it was Jacek flying, not any fly (child laughs).

'Cos Jacek was naughty and Wacek (too).

And they went out of the house.' [K.D. 4;7]

(7) Taki chłopczyk na rowerku patrzy w Jacka, jak wyciaga Wacka.

I się boi, co Jacek nie tak mocno trzyma za tapę Wacka.

Tylko trzy palce dat (pokazuje)

Ale to nieprawda. Mocniej trzyma Jacek.

Z cała łapq (pokazuje pięć palców), tak (demonstruje) trzyma Wacka.

'There's a little boy on a bicycle looking at Jacek how he is pulling Wacek out. And he is scared that Jacek isn't holding Wacek's paw hard.

He gave only three fingers (showing).

But that's not true. Jacek is holding onto Wacek harder.

With his whole paw (showing five fingers), he's holding onto Wacek

this way (showing)' [Z.R. 5;4]

\section{Possible (but uncertain) interpretations}

(8) Jacek fruwat nad takq. I spadat, i spadat.

Kasia zgłówkowała, co może stabo machat za skrzydetka i słabo ruszał nóżkami.

A myszka myślała, co nie miat w środku powietrza.

No może, nie wiadomo.

A ja myślę, co chyba ruszat skrzydtami Jacek, a potem nóżkami...

A potem raz skrzydtami, i raz nóżkami.

A potem raz zapomniat. I tylko się patrzyt... z góry. Nie wiadomo.

I spada ${ }^{3}$ spada ${ }^{3}$. A na koniec spad?

'Jacek was flying over the field. And he was falling and falling.

Kasia was using her head to think hard. She thought that maybe he wasn't waving his wings well enough and wasn't kicking his legs well enough.

And the little mouse was thinking that he didn't have air inside him.

Maybe, you can't tell.

And I think that maybe Jacek waved his wings and then kicked his feet. 
And then first his wings, then his feet.

And then once he forgot. And just only looked... down. You can't tell.

And he was falling, and falling.

And at the end he just fell down.' [C.N. 6;8]

Thus narrators not only attributed interpretations to field participants, but also performed reference operations upon the attributed interpretations:

- Supplementation of field subject's knowledge in cases of incomplete interpretations;

- Negation/Modification of field subject's interpretations in cases of wrong interpretations;

- Confirmation that an uncertain interpretation by a field subject is possible, sometimes adding his/her own possible interpretation (see above examples), thus testifying to the narrator's uncertainty as to the correct interpretation.

Figure 2 presents frequencies of the different kinds of narrator operations upon the contents of mental states attributed to narrative field participants.

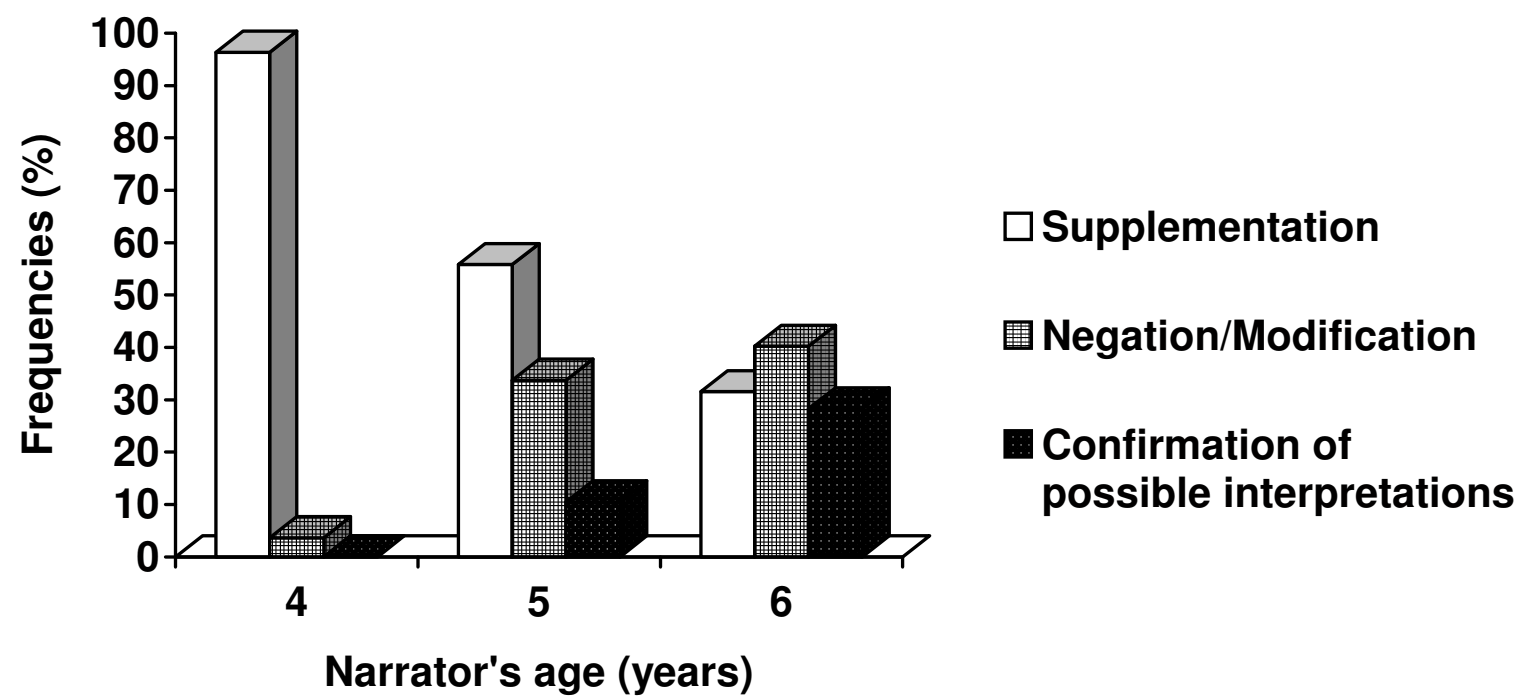

Fig. 2. Reference operations performed by the narrator upon field subjects' representations of heroes' adventures

A loglinear analysis based on the empirical data showed a significant main effect $\left[\mathrm{L}^{2}(2)=28.28403, \mathrm{p}<0.000001\right]$ of the interaction between narrator's age and different kinds of reference operations performed by the narrator upon field subjects' representations of the main action (see detailed data in Appendix 2). 
In light of the above analyses of the data we can answer the questions posed in this study as follows:

Preschool children start to produce stories with a dual landscape. We found a developmental change in the way narrative constructions are built. Starting with 4-yearolds, narrators co-construct with narrative field subjects a representation of the main action line. They ascribe some questions to these subjects and then they answer these questions. With 5- and 6-year-olds we observed a new way of constructing dual representations (that of narrator and that of field subjects) by confrontation of different representations leading to the narrator deciding on the true version of the main action. But not always is the narrator sure of the true version: Sometimes he or she responds to the version presented by the field subject (imputed by himself/herself to this subject) by presenting still another possible version which may or may not be the true one. Only in this case does the narrator use modal forms such as perhaps, maybe, and uses as well performative (illocutionary) verbs like think in first person (I think that...).

\section{Discussion}

Following Bruner's theory, narrative requires:

1/ "agentivity" - action directed toward goals controlled by agents;

2/ linearization of events and states;

$3 /$ sensitivity to what is canonical and what violates canonicality in human interaction;

4/ something approximating a narrator's perspective - narrative cannot, in the jargon of narratology, be "voiceless" (see Bruner 1990: 77).

This paper focuses on voices of the narrator's mind (see Voices of the mind by Wertsch 1991). The same adventures shown in the pictorial material are narrated differently depending on how the story-teller "reads" the minds of narrative subjects. In the light of our studies, the preschool narrator uses field subjects' minds to better understand the course of changes in referenced reality and to explain states and actions in the narrative line. The narrator takes different perspectives which he/she attributes to story characters who are located in the narrative field and are observing the foreground events. By age three most children are explicitly aware that looking leads to knowing (Pratt \& Bryant 1990: 980). Many studies provide clear evidence that children are able to make correct judgments about the mental states of individuals who have or have not had visual access to something (ibid: 980; see also Pillow 1989; Bartsch \& Wellman 1998; Bokus 1991, 1998), here: To actions of the heroes of the narrative line. Apparently making other persons (observers of the foreground events) think about the story forces the narrator to incorporate their perspectives. So the narrative text contains not only the action presented by the story-teller (in the landscape of action) but also how this action is interpreted by the characters of the story (landscape of consciousness). As said above, they are all thinking minds that can think similarly or differently about the plot. And the narrator uses characters' minds either to coproduce one representation (answering questions ascribed to field subjects) or to produce different representations of the story. He/she can confront one interpretation with another, and can do the following: The narrator can choose the "true" representation of the main 
action or can present a possible - but not a certain - story reality. In the first case, the child acts as the omniscient and omnipresent story-teller directly in touch with the ontology of the story. In the second case, the child presents a possible story reality. The listener is not told how things are but how they seem to be. Therefore we can speak about an interplay of the narrator's mind and the minds of story characters in a kind of internal narrator's dialogue.

The story-teller creates different minds and alternative ways of interpreting the main action. We here show examples of such inter-mind phenomena in the stories told by preschool children. From these examples a narrative can be conceived of as multivoiced like in Hermans' theory of a self-narration (1997: 260) and, earlier, in Bakhtin's view (1973, see also Wertsch 1991). Different interpretations (by the narrator and by peer or non-peer characters) of the foreground action are presented in a dialogical fashion. The main strategy of the narrator's dialogue is to attribute to story characters representations of the changing reality and to perform basic operations upon attributed representations from the perspective of the narrator's image of what was going on. Co-construction of reference reality enriches the meaning potential of narrative discourse. The same foreground reality is shown to be described and explained in various ways. The narrator's perspective selects one, or even more than one, of these ways in narrative construction. The results of our study can be explained in terms of Shield's (1978) conception, formulated as follows:

"The child's image of the world is mirrored twice, once directly and again as a representation of the representations of others. (...) Each image modifies and extends the other" (Shields 1978: 556).

Our study shows that narrators' direct representations of what happened to foreground heroes interacted with narrators' representations of the representations of background characters (adult or peer participants in the narrative field) in reference to heroes' actions. This interaction affected the course of the narrative line (more details in Bokus 2000) resulting in different elaborations of the semantic structure of stories, i.e., either of the external circumstances of episodic actions (in categories of causes and consequences of heroes' actions), or of the plan of episodic actions ( in categories of heroes' motives, action steps and action results).

The results presented in this article are in accordance with findings of Nicolopoulou's empirical project mentioned here at the beginning. Nicolopoulou and Richner summarized results of their study in the following way: "The study (...) demonstrates that children can portray psychological characters in their stories beginning around age 4" (see Nicolopoulou \& Richner 1999a: 5). The results of our research not only provide clear evidence that 4-7- year-old narrators attribute some mental states to story characters but also show how narrators use these mental attributions in order to construct (rather: Co-construct) the content of a story line.

\section{References:}

Abbeduto, L., and S. Rosenberg (1985) Children's knowledge of the presuppositions of know and other verbs. Journal of Child Language 12: 621-641. 
Astington, J.W. (1990) Narrative and the child's theory of mind. In B.K. Britton, \& A.D. Pellegrini (eds.), Narrative thought and narrative language. Hillsdale, NJ: Erlbaum, pp. 151-171.

Astington, J.W. (1993) The child's discovery of the mind. Cambridge, MA: Harvard University Press.

Bakhtin, M. (1984) Problems of Dostoevski's poetics. Minneapolis: University of Minnesota Press.

Bamberg, M. (ed.) (1997) Narrative development: Six approaches. Mahwah, NJ: Erlbaum.

Bamberg, M., and R. Damrad-Frye (1991) On the ability to provide evaluative comments: Further explorations of children's narrative competence. Journal of Child Language 18: 689-710.

Bartsch, K., and H.M. Wellman (1995) Children talk about the mind. New York: Oxford University Press.

Bokus, B. (1991) Children's pragmatic knowledge of narrative tasks. In J. Verschueren (ed.), Pragmatics at issue. Vol. 1 (Selected papers of the International Pragmatics Conference, Antwerp - 1987). Amsterdam: John Benjamins Publishing Company, pp. 13-28.

Bokus, B. (1992) Peer co-narration: Changes in structure of preschoolers' participation. Journal of Narrative and Life History 2: 253-275.

Bokus, B. (1996a) Action and consciousness: Duality of children's narrative construction. Paper presented at the VIIth International Congress for the Study of Child Language (Istanbul, July 14-19, 1996).

Bokus, B. (1996b) Narrative space structuring at the preschool age (Findings on monologic and dialogic discourse. In C.E. Johnson \& J.H.V. Gilbert (eds.), Children's Language, vol. 9. Mahwah, NJ: Erlbaum, pp. 197-207.

Bokus, B. (1998) Action and its representation in the minds of story characters. Findings from children's discourse. Psychology of Language and Communication 2.2: 63-77.

Bokus, B. (2000) Światy fabuły w narracji dziecięcej (Story worlds in child narration). Warsaw: Energeia.

Britton, B.K., and A.D. Pellegrini (eds.) (1990) Narrative thought and narrative language. Hillsdale, NJ: Erlbaum.

Bruner, J. (1986) Actual minds, possible worlds. Cambridge, MA: Harvard University Press.

Bruner, J. (1990) Acts of meaning. Cambridge, MA: Harvard University Press.

Donaldson, M. (1978). Children's minds. New York: Norton.

Eco, U. (1994) Lector in fabula. Warszawa: PIW.

Ely, R., A. McCabe, A. Wolf, and G. Melzi (2000) The story behind the story: Gathering narrative data from children. In L. Menn, \& N.B. Ratner (eds.), Methods for studying language production. Mahwah, NJ: Erlbaum, pp. 249- 269.

Flavell, J.H., and P.H. Miller (1998) Social cognition. In D.Kuhn, \& R. Siegler (eds.), Cognition, perception, and language. Vol. II of W. Damon (Gen.ed.), Handbook of child psychology. New York: Wiley, pp. 851898.

Fox, R. (1991) Developing awareness of mind reflected in children's narrative writing. British Journal of Developmental Psychology 9: 281-298.

Gopnik, A., and A.N. Meltzoff (1997) Words, thoughts, and theories. Cambridge MA: MIT Press. 
Halliday, M.A.K., and R. Hasan (1976) Cohesion in English. London: Longman.

Hermans, H.J.M. (1997) Self-narrative in the life course: A contextual approach. In M. Bamberg (ed.), Narrative development: Six approaches.Mahwah, NJ: Erlbaum, pp. 223 -264.

Hudson, J.A., and L.R. Shapiro (1991) From kowing to telling: The development of children's scripts, stories, and personal narratives. In A. McCabe, \& C. Peterson (eds.), Developing narrative structure. Hillsdale, NJ: Erlbaum, pp. 89-136.

Kielar-Turska, M. (1999) The inner landscape of characters in stories told by children. Psychology of Language and Communication 3.2: 49-56.

Labov, W., and J. Waletzky (1967) Narrative analysis: Oral versions of personal experience. In J. Helm (ed.), Essays on the verbal and visual arts. Seattle: University of Washington Press, pp. 12-44.

Lewis, C., N.H. Freeman, C. Hagestadt, and H. Douglas (1994) Narrative access and production in preschoolers' false belief reasoning. Cognitive Development 9: 397-424.

Lucariello, J. (1990) Canonicality and consciousness in child narrative. In B.K. Britton, \& A.D. Pellegrini (eds.), Narrative thought and narrative language. Hillsdale, NJ: Erlbaum, pp. 149.

Lyons, J. (1977) Semantics, vol. 2. Cambridge: Cambridge University Press.

Macnamara, J., E. Baker, and C. Olson (1976) Four-year-olds' understanding of pretend, forget and know: Evidence for propositional operations. Child Development 47: 62-70.

Mandler, J.M. (1998) Representation. In D. Kuhn, \& R.S. Siegler (eds.), Cognition, perception, and language: Vol. 2, W. Damon (ed.), Handbook of child psychology. New York: Wiley, pp. 255-281.

Musatti, T. (1986) Early peer relations: The perspectives of Piaget and Vygotsky. In E.C. Mueller, \& C.R.Cooper (eds.), Process and outcome in peer relationships. Orlando: Academic Press, pp. 25- 53.

Nicolopoulou, A., and E.S. Richner (1999a) From actors to characters to persons: The development of character representation in young children's narratives. Poster presented at the 1999 Biennial Meeting of the Society for Research in Child Development. Albuquerque (April 15-18, 1999), (work in progress), NM.

Nicolopoulou, A., and E.S. Richner (1999b) The development of main character in young children's narratives. Paper presented at the VIIIth Congress for the Study of Child Language, San Sebastian (July 1216, 1999), NM.

Pillow, B.H. (1989) Early understanding of perception as a source of knowledge. Journal of Experimental Child Psychology 47: 116-129.

Pratt, C., and P. Bryant (1990) Young children understand that looking leads to knowing. Child Development 61: 973-982.

Searle, J.R. (1983) Intentionality: An essay in the philosophy of mind. New York: Cambridge University Press.

Searle, J.R. (2002) Consciousness and language. Cambridge: Cambridge University Press.

Shields, M. (1978) The child as psychologist: Construing the social world. In A. Lock (ed.), Action, gesture, and symbol: The emergence of language. London: Academic Press, pp. 529-561.

Shugar, G.W. (1976) Text-constructing with an adult. A form of child activity during early language acquisition. In D. Drachman (ed.), Akten des 1. Salzburger Kolloquiums über Kindersprache. 
Tübingen:Verlag Gunter Narr, pp. 343-356.

Shugar, G.W. (1998) Entry into narration: Uses of operation of reference. Psychology of Language and Communication 2.2: 7-16.

Stein, N.L., and E.R. Albro (1997) Building complexity and coherence: Children's use of goal-structured knowledge in telling stories. In M. Bamberg (ed.), Narrative development: Six approaches. Mahwah, NJ: Erlbaum, pp. 5-44.

Taylor, M. (1996) A theory of mind perspective on social development. In R. Gelman, \& T.K.-F. Au (eds.), Perceptual and cognitive development. San Diego, CA: Academic Press, pp. 283-329.

Tomasello, M. (1999) The cultural origins of human cognition. Cambridge, MA: Harvard University Press.

Tomaszewski, T. (1975) Człowiek i otoczenie (Man and environment). In T. Tomaszewski (ed.), Psychologia. Warsaw: PWN, pp. 13-36.

Wertsch, J.V. (1991) Voices of the mind. A sociocultural approach to mediated action. Cambridge, Mass.: Harvard University Press.

\section{Appendix 1.}

Examples of two variants of picture-book A 
406 Barbara Bokus
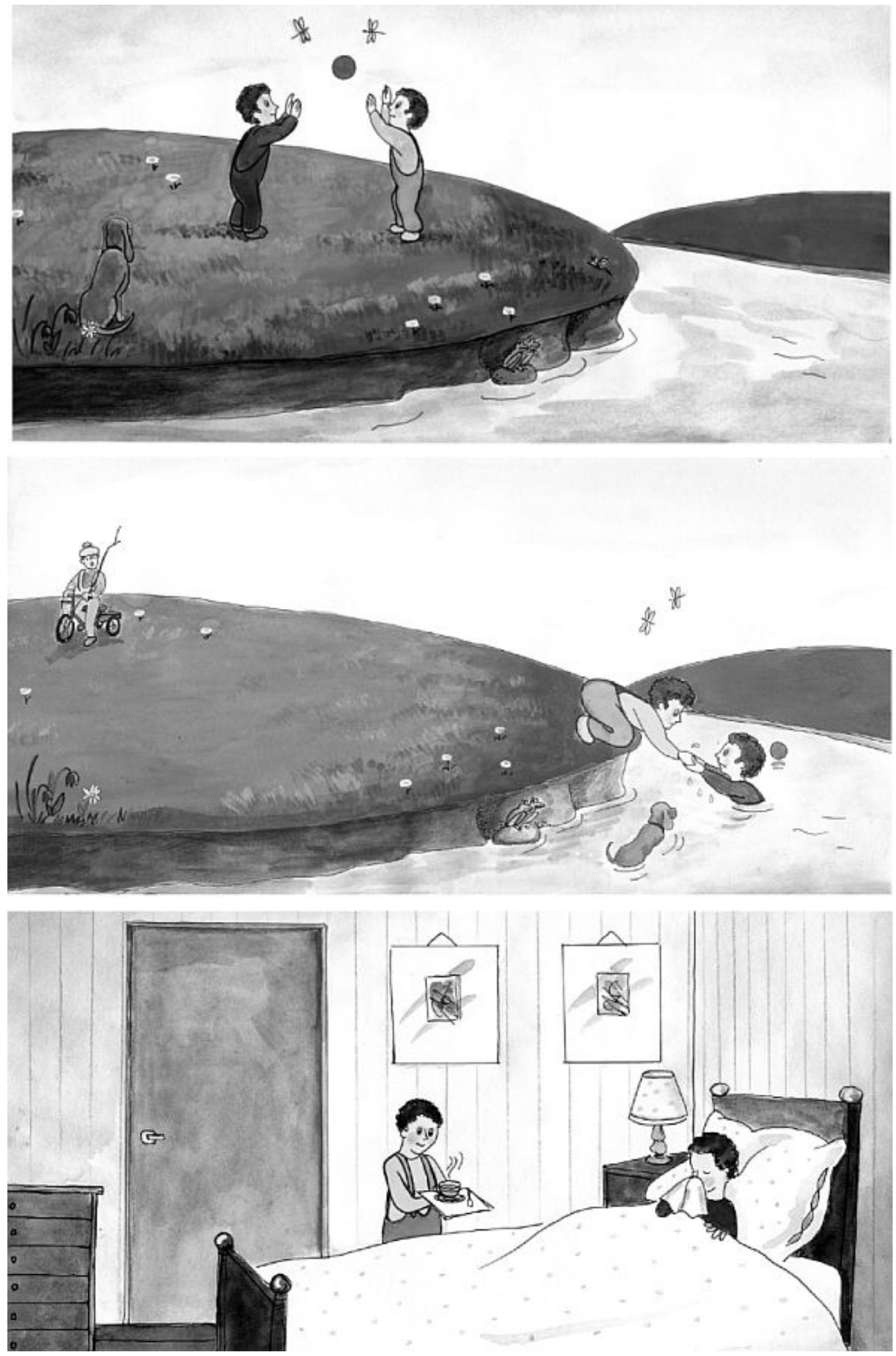

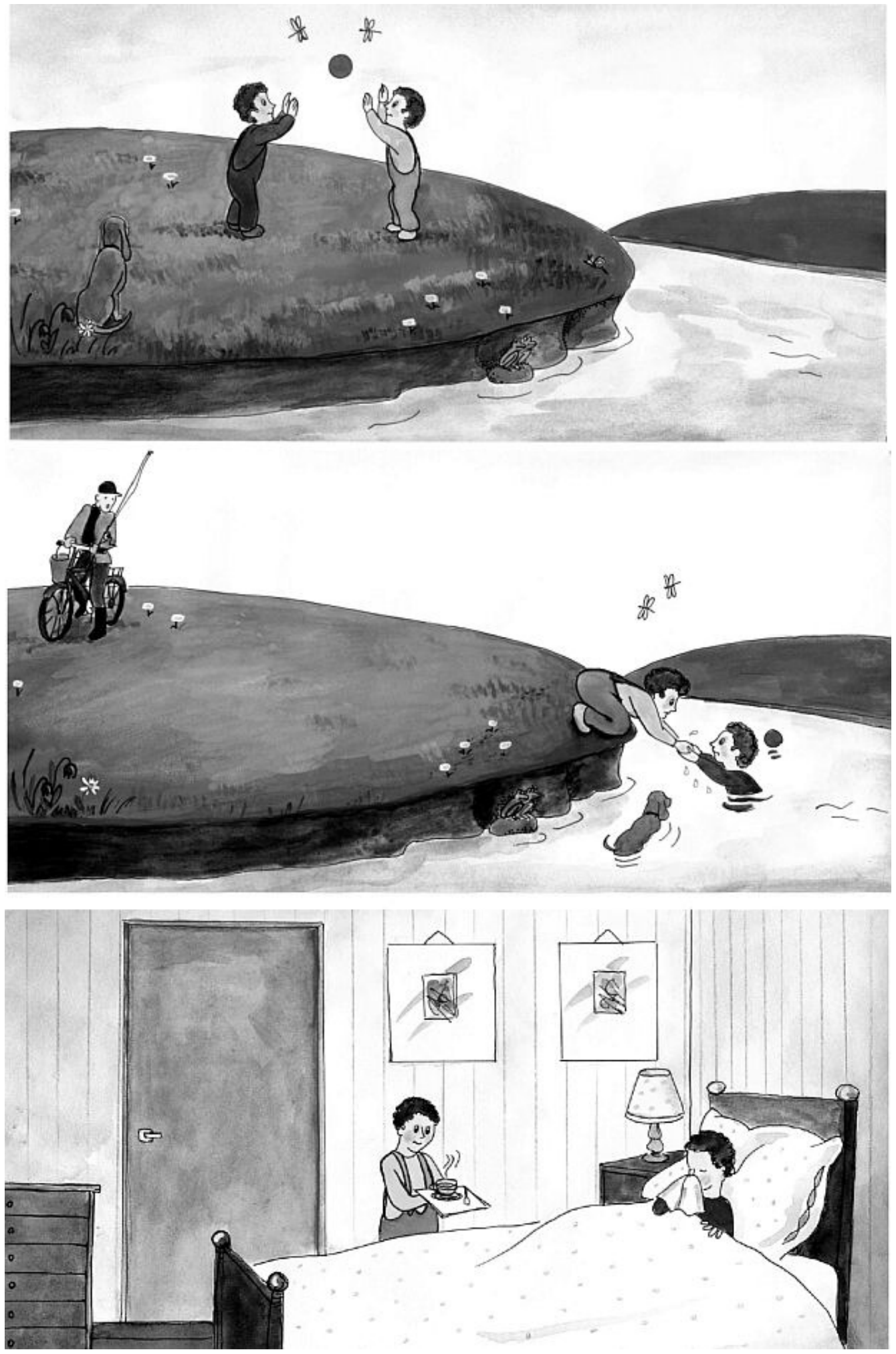


\section{Appendix 2.}

Results of loglinear analysis based on the empirical data Main features:

1. Narrator's age

2. Pictorial material

3. Narrative field subject (child, adult)

4. Mental attribution

5. Reference operation upon mental attribution

\begin{tabular}{|c|c|c|c|c|c|}
\hline Effect & $\begin{array}{l}\text { Degrs.of } \\
\text { Freedom }\end{array}$ & $\begin{array}{l}\text { Prt.Ass. } \\
\text { Chi-sqr. }\end{array}$ & $\begin{array}{l}\text { Prt.Ass. } \\
\text { p }\end{array}$ & $\begin{array}{l}\text { Mrg.Ass. } \\
\text { Chi-sqr. }\end{array}$ & $\begin{array}{l}\text { Mrg.Ass. } \\
\text { p }\end{array}$ \\
\hline 1 & 2 & 2.91835 & .232443 & 2.91835 & .232443 \\
\hline 2 & 2 & 29.63397 & .000000 & 29.63397 & .000000 \\
\hline 3 & 1 & 7.74048 & .005403 & 7.74048 & .005403 \\
\hline 4 & 1 & 16.38945 & .000052 & 16.38945 & .000052 \\
\hline 5 & 1 & 10.25775 & .001362 & 10.25775 & .001362 \\
\hline 12 & 4 & .56021 & .967380 & .71996 & .948844 \\
\hline 13 & 2 & 1.60700 & .447768 & 1.00977 & .603581 \\
\hline 14 & 2 & .41912 & .810941 & .02351 & .988312 \\
\hline 15 & 2 & 28.18393 & .000001 & 28.28403 & .000001 \\
\hline 23 & 2 & .23139 & .890748 & 2.42799 & .297022 \\
\hline 24 & 2 & 3.08864 & .213473 & 5.41162 & .066831 \\
\hline 25 & 2 & .90868 & .634870 & 1.23332 & .539750 \\
\hline 34 & 1 & 90.35529 & .000000 & 92.12758 & .000000 \\
\hline 35 & 1 & .02709 & .869272 & .04243 & .836795 \\
\hline 45 & 1 & .10216 & .749253 & .42889 & .512537 \\
\hline 123 & 4 & .28882 & .990524 & .79356 & .939307 \\
\hline 124 & 4 & .55740 & .967677 & .56721 & .966635 \\
\hline 125 & 4 & 2.03127 & .730007 & 1.74095 & .783265 \\
\hline 134 & 2 & .36258 & .834193 & .45623 & .796034 \\
\hline 135 & 2 & .08883 & .956557 & .18318 & .912479 \\
\hline 145 & 2 & 63829 & .726772 & .53902 & .763757 \\
\hline 234 & 2 & 2.92233 & .231982 & 3.17101 & .204860 \\
\hline 235 & 2 & .54821 & .760254 & 1.25662 & .533499 \\
\hline 245 & 2 & .01267 & .993687 & .50119 & .778339 \\
\hline 345 & 1 & .00367 & .951677 & .00562 & .940226 \\
\hline 1234 & 4 & .24699 & .992974 & .28902 & .990512 \\
\hline 1235 & 4 & 2.57260 & .631688 & 2.38547 & .665258 \\
\hline 1245 & 4 & 3.16832 & .530072 & 3.67171 & .452268 \\
\hline 1345 & 2 & 4.87046 & .087594 & 5.00610 & .081851 \\
\hline 2345 & 2 & .24579 & .884359 & .25650 & .879632 \\
\hline
\end{tabular}

